\begin{tabular}{|c|c|}
\hline Вісник & $\begin{array}{c}\text { Astronomical } \\
\text { Aстрономічної } \\
\text { School's } \\
\text { школи }\end{array}$ \\
\hline
\end{tabular}

ISSN 2411-6602 (Online)

ISSN 1607-2855 (Print)

Volume $\mathbf{1 6} \bullet$ Issue $2 \bullet \mathbf{2 0 2 0} \quad$ P. $43-47$

https://doi.org/10.18372/2411-6602.16.07

UDC 523.68

\title{
Physical characteristics of space invasion
}

\section{B.E. Zhilyaev, A.P. Vidmachenko*, A.F.Steklov}

The Main Astronomical Observatory of the NAS of Ukraine, 03143, Academician Zabolotny str., 27, Kyiv, Ukraine

This paper presents an example of the application of theoretical developments on some issues of physics of space invasion. The effect of brightness oscillations and "wobbling" in the meteor trail, which we discovered, allows us to obtain estimates of some characteristics of the meteor by measuring the frequency of changes in the brightness in the trace $\left(f_{c}\right)$ and meteoroid oscillations $\left(f_{m}\right)$, if its velocity and altitude are known. Based on the proposed "tuning technique", it is possible to determine the characteristics of the meteor at one-sided observations. To do this, we set the initial parameters for the model of meteoroid dynamics by the coincidence of the calculated and measured values of the frequencies $f_{c}$ and $f_{m}$. Our simulation allows us to find the altitude at which the ratio of frequencies $f_{c} / f_{m}$ coincides with the value found in the explosion of a meteoroid. Using this "tuning technique" and assuming the mineral composition for the meteor, we found estimates of the initial velocity of $21 \mathrm{~km} / \mathrm{s}$ and the mass of $850 \mathrm{~kg}$ of the meteoroid, which reached a critical value of surface speed at an altitude of about $20.9 \mathrm{~km}$ in about $7.9 \mathrm{~s}$ with a residual mass of about $13.9 \mathrm{~kg}$ and a residual speed of about $10.9 \mathrm{~km} / \mathrm{s}$. At that moment, the meteoroid exploded.

Keywords: space invasions, astronomical observations, photometry, meteors.

\section{INTRODUCTION}

The inspiring image was snapped by photographer Krista Trinder, which was 19/11/2020 honoured as NASA's Astronomy Picture of the Day (Fig. 1). This photo depicts a landscape over Childs Lake, Canada, captured with long exposure [10]. Such celestial phenomenon known in scientific circles as the "Strong Thermal Emission Velocity Enhancement", or "STEVE" for short, is seen shimmering over the horizon. This phenomena has been frustrating perplexed scientists at US-based space agency NASA for years. Such light was first confirmed five years ago, but experts remain puzzled as to its cause. The colourful streaks consist of a "purple ribbon in the sky, with a green picket fence structure underneath", NASA said in an accompanying statement. The space agency added it as "aurora-like", meaning it seems to resemble the natural electric phenomenon responsible for the world-famous Northern Lights.

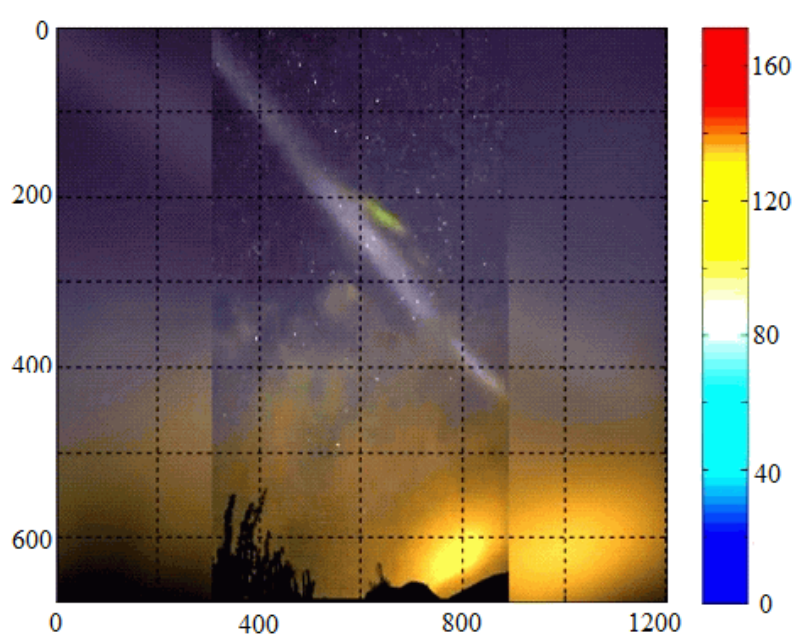

Fig. 1. Field observation of the intrusion in Canada. The meteoroid inversion trace, which indicates its movement in the atmosphere of the Earth.



Fig. 2. Photometry of the image in Fig. 1

We consider this image as a trace of a meteoroid that entered the atmosphere at an angle of 36 degrees and at a positional angle of 6 degrees. It follows from the image that the explosion occurred at the coordinate $X=200$ and the pieces then fell apart.

\section{THEORY}

Fig. 3 shows the light curve of the centre of gravity of the inversion trace with the oscillation frequency of $1.66 \mathrm{~Hz}$ (drag frequency $f_{c}$ ) on a time scale of 7.9 seconds. The wobbling frequency of the centre of gravity

*Vidmachenko Anatoliy Petrovych; $₫$ vida@mao.kiev.ua 

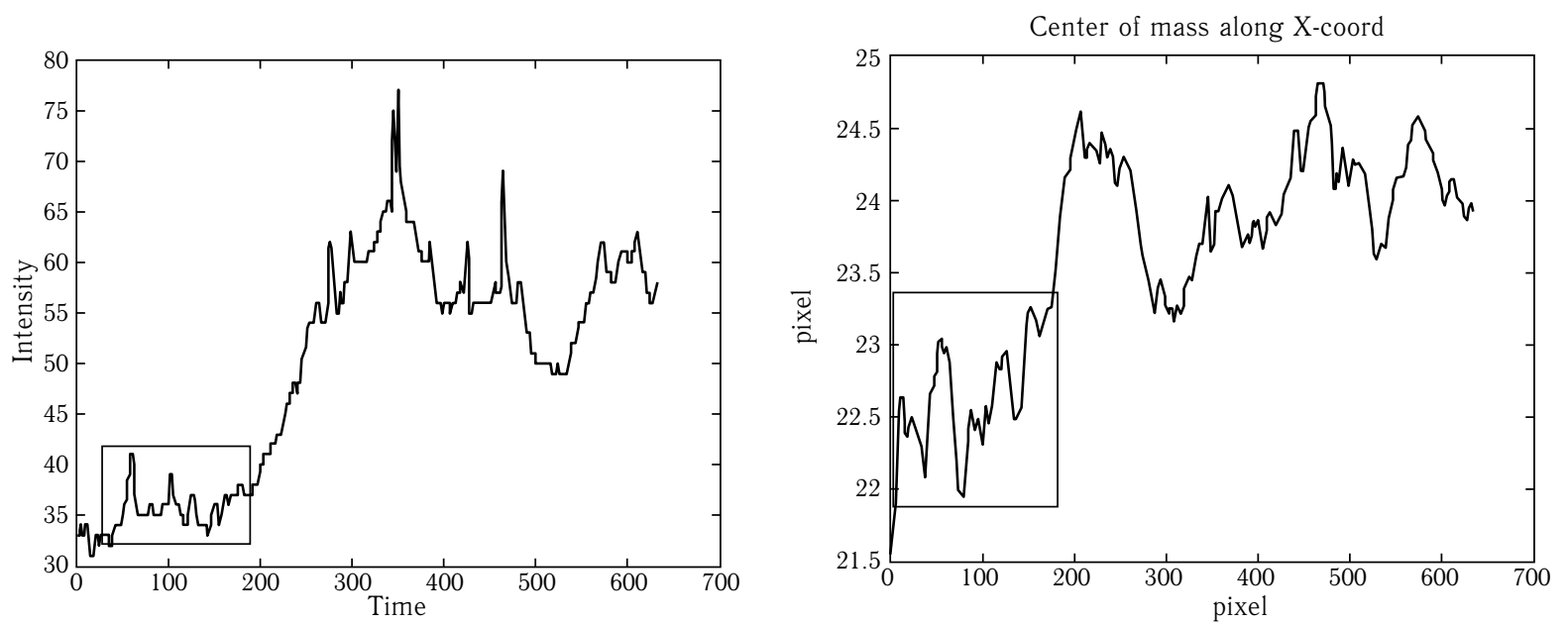

Fig. 3. The light curve of the centre of gravity of the inversion trace

of the inversion trace $f_{m}$ is estimated at $1.12 \mathrm{~Hz}$.

It is well known that a swirling ball flies along a curved path. Deviations from rectilinear motion indicate the presence of strength perpendicular to the direction of the flight path. This phenomenon is known as the Magnus effect. It occurs when a stream of gas flows around a rotating body.

The equation of motion of a meteoroid of mass $m$ and velocity $v$ is written in the form:

$$
m \overrightarrow{\mathbf{v}}=\overrightarrow{\mathbf{F}}_{c}+\overrightarrow{\mathbf{F}}_{m}
$$

where the aerodynamic drag force $F_{c}$ and the Magnus force $F_{m}$ acting on the meteoroid. The aerodynamic drag force $F_{c}$ is:

$$
F_{c}=\frac{1}{2} C_{D} \rho v_{\infty}^{2} \pi r_{m}^{2}
$$

where $C_{D}$ is the drag coefficient depends on the shape of the body. The simplest expression for the Magnus lifting force $F_{m}$ is known for a cylindrical body [1]:

$$
\overrightarrow{\mathbf{F}}_{m}=2 S \rho r_{m}\left[\overrightarrow{\mathbf{v}} \times \vec{\omega}_{m}\right],
$$

where $S=\pi r_{m} L_{m}$ is an area of a cylinder, $r_{m}$ and $L_{m}$ are the radius and length of the cylinder, $\rho-$ gas density, $v-$ flow velocity at infinity, $\omega_{m}$ is the frequency of angular rotation.

In the linear approximation, we can neglect variations of $v$ within $H_{\rho}$ along the meteoroid track $z$, where $H_{\rho}$ is the height of the homogeneous atmosphere, approximately $7 \mathrm{~km}$.

In this approximation the equation of motion of a meteoroid give the oscillation solutions [2].

The angular frequency of the brightness variations $\Omega_{c}$ has the form

where $\rho_{m}$ is the density of meteoroid.

$$
\Omega_{c}=2 \pi f_{c}=\sqrt{\frac{3}{4} \frac{C_{D} \rho v^{2}}{r_{m} \rho_{m} H_{\rho}}},
$$

The main frequency of rotation of Magnus $\Omega_{m}$ has the form

$$
\Omega_{m}=2 \pi f_{m}=\frac{3}{2} \frac{\rho \omega_{m}}{\rho_{m}}\left(1+\frac{z}{H_{\rho}}\right) .
$$

A meteoroid can be considered as an air turbine that converts the energy of the airflow into rotational energy. We can obtain an estimate the angular frequency of the rotation of the meteoroid as [3]:

$$
\omega_{m}=\sqrt{\frac{C_{P} \rho v^{3} S T}{I}}
$$

Here $T$ is the time span, $I$ is the moment of inertia around the axis of rotation.

Most meteoroids end with an explosion. As the meteoroid moves the atmospheric density increases and the stagnation pressure at the meteoroid $p_{s}=\rho v^{2}$ rises, up to destruction value $p_{s}=Y$, where $Y$ is Young's modulus. Destruction of a meteoroid occurs also when the centrifugal force arising from rotation becomes equal to the normal force determining the tensile strength of the material of which the meteor consists $Y=\rho_{m} \omega_{m}^{2} r_{m}^{2}=\rho_{m} v_{m}^{2}$, where $v_{m}$ - rotation speed on the meteoroid surface.

Laboratory studies have shown that the tensile strength $\mathrm{Y}$ for different samples of stone meteorites varies in the range of 20 to $200 \mathrm{MPa}$ [4]. Thus, the value of the velocity $v_{m} \approx 3 \mathrm{~km} / \mathrm{s}$ can be considered as a conditional value for meteoroid of mineral composition. 


\section{MODEL OF THE ABLATION FOR ESTIMATION THE METEOROID CHARACTERISTICS}

Last time the computer program has been developed for estimating the environmental consequences of an asteroid impact on Earth. The program requires six inputs: impactor diameter, impactor density, impact velocity before atmospheric entry, impact angle, and the target type (sedimentary rock, crystalline rock) $[7,6]$. The motion of a meteoroid through the atmosphere in 3D simulations was performed by set of authors $[7,8]$. We use the classical meteor ablation theory $[6,9]$.

The model can be implemented by the Impact 4A Software [6]. The numerical integration of the differential equations was performed using the Runge-Kutta 4 integrator. This was found to be stable at time steps of $0.001 \mathrm{~s}$. We construct a grid of intrusion models using the Impact $4 \mathrm{~A}$ software program on the plane of the

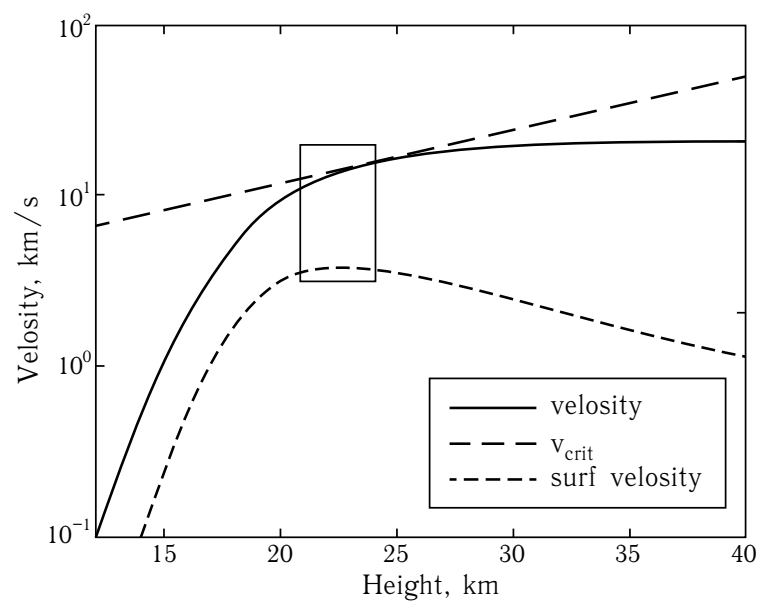

Fig. 4. The speed of the meteoroid depending on the height, the speed of rotation on the surface and the critical speed of dynamic destruction
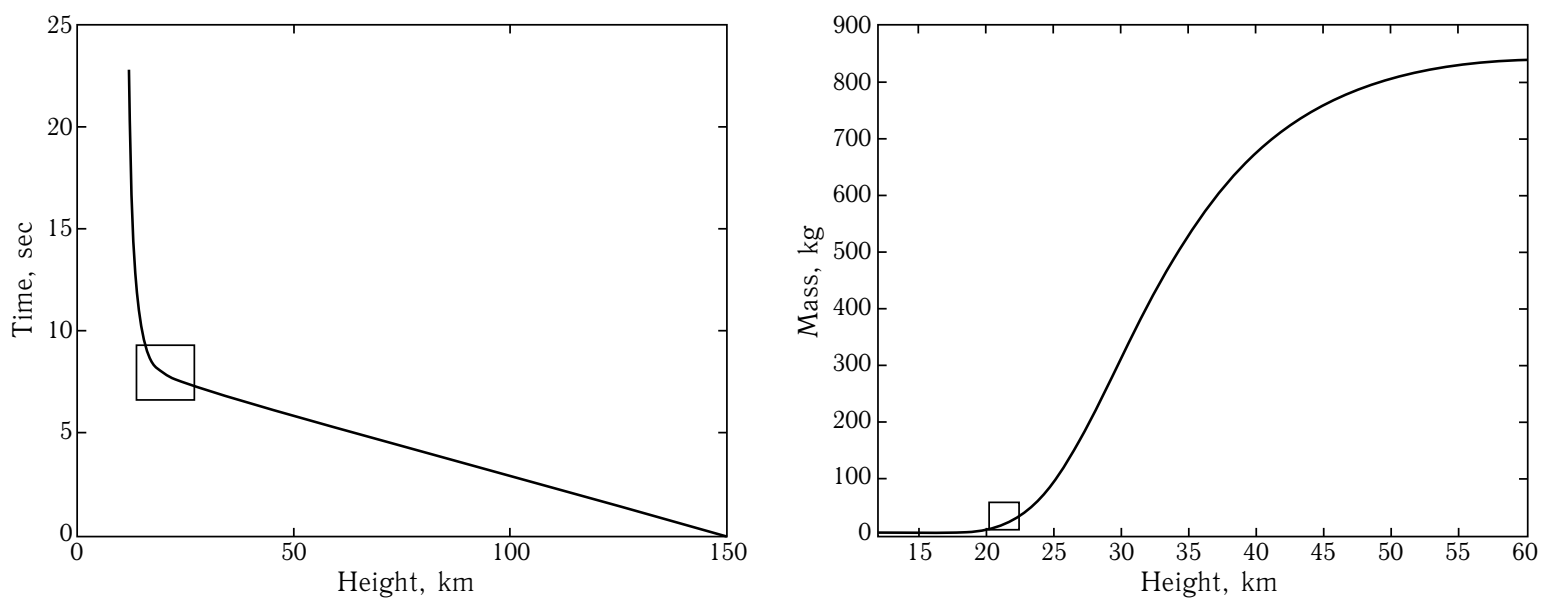

Fig. 5. The time span and the value of the meteoroid mass depending on the height


Fig. 6. The values of the frequencies $f_{c}, f_{m}$ depending on the height (left). The frequency ratio $f_{c} / f_{m}$ coincides with the value found from the measurements on the height of $20.9 \mathrm{~km}$, on a time of $7.9 \mathrm{sec}$ (right). At this moment a meteoroid exploded and destroyed. 
primary "mass - speed" meteoroid. As a result of modelling, we find the height at which the frequency ratio $f_{c} / f_{m}$ coincides with the value found from measurements for exploding meteoroid.

\section{COMPARISON OF THEORY AND OBSERVATIONS}

The ablation of an $850 \mathrm{~kg}$ solid meteoroid with an initial velocity of $21 \mathrm{~km} / \mathrm{s}$ was simulated using the Impact 4A Software considered above [6].

Fig. 4 shows the speed of the meteoroid depending on the height, the speed of rotation on the surface and the critical speed of dynamic destruction. It is easy to see that the limit of dynamic fracture was reached.

The meteoroid reached a critical value of the stagnation pressure at an altitude of $20.9 \mathrm{~km}$ in a time of about $7.9 \mathrm{sec}$ with a residual mass of $13.9 \mathrm{~kg}$, and a residual speed of $10.9 \mathrm{~km} / \mathrm{s}$ (Fig. 5). At this moment a meteoroid exploded and destroyed.

Fig. 6 plays a crucial role in our work. The figure shows the values of the frequencies $f_{c}, f_{m}$ depending on the height. By varying the initial parameters of the model, the primary mass and speed of the meteoroid at the boundary of the Earth's atmosphere, we find the height at which the frequency ratio $f_{c} / f_{m}$ coincides with the value found from the measurements on time of $7.9 \mathrm{~s}$.

\section{METEOROID'S CHARACTERISTICS.}

1. A parent object weighing $850 \mathrm{~kg}$ entered the atmosphere at a speed of $21 \mathrm{~km} / \mathrm{s}$.

2. Burned, lost mass, rotated, shone like Venus.

3. After about 8 seconds it exploded at an altitude of about $21 \mathrm{~km}$. The residual mass of about $14 \mathrm{~kg}$ at a speed of $11 \mathrm{~km} / \mathrm{sec}$ fell apart into several fragments, which continued to fall.

Thus, we show that "tuning technique" in combination with a simulation model of intrusion allows determining the meteor characteristics during one-side observations [11-16].

1. Prandtl L. // Uspekhi Fizicheskikh Nauk. - 1925. - Vol. V, No. 1-2. - P.1-27.

2. Zhilyaev B.E., Vidmachenko A.P., Steklov A.F. et al. The physics of space intrusions. I. Features of the trajectories // Astron. School's Report. - 2020. - Vol. 16, No. 1. - P.8-15. https://doi.org/10.18372/2411-6602.16.02

3. Betz A. Introduction to the Theory of Flow Machines. - Oxford, Pergamon Press, 1966.

4. Slyuta E.N. Physical and Mechanical Properties of Stone Meteorites // Astronomical Bulletin. - 2017. - Vol. 51. No. 1. - P.72-95.

5. Collins G.S., Melosh H.J., Marcus R.A. // Meteoritics \& Planetary Science. - 2005. - Vol. 40, No. 6. - P.817-840. https://doi.org/10.1111/j.1945-5100.2005.tb00157.x

6. Downs B. Impact 4A Software. Meteor Atmospheric Flight, 1998. https://www.spaceacademy.net.au/watch/debris/metflite.htm

7. Popova O.P., Sidneva S.N., Strelkov A.S., Shuvalov V.V. Formation of Disturbed Area Around Fast Meteor Body // Proc. of the Meteoroid 2001 Conf. 6-10 August 2001 (ESA SP-495, November 2001). - P.237-245.

8. Mehta C., Perez A., Thompson G., et al. // Life. - 2018. - Vol. 8, No. 13. https://doi.org/10.3390/life8020013

9. Campbell-Brown M.D., Koschny D. // Astron. and Astrophys. - 2004. - Vol. 418. - P.751-758. https://doi.org/10.1051/0004-6361:20041001-1

10. https://www.express.co.uk/news/science/1361943/nasa-pictures-steve-colourful-lights-aurora-northern-lights-evg

11. Dashkiev G.N., Zhilyaev B.E., Steklov A.F., et al. Interesting fireball invasion in the sky over Kiev // 50th Lunar and Planetary Science Conference, held 18-22 March, 2019 at The Woodlands, Texas. LPI Contribution No. 2132, id.1195. https://ui.adsabs.harvard.edu/abs/2019LPI....50.1195D/abstract

12. Kondratyuk R.R., Zhilyaev B.E., Vidmachenko A.P., et al. Observations of daytime meteors // 20-th Gamow International Astronomical Conference-School "Astronomy and beyond: astrophysics, cosmology and gravitation, high energy physics, astroparticle physics, radioastronomy and astrobiology”, Ukraine, Odessa, August 9-16, 2020. P.24-25. https://ui.adsabs.harvard.edu/abs/2020abac.conf...29K/abstract

13. Mozghovyi O., Kondratyuk R.R., Zhilyaev B., et al. Tropospheric meteors // Astronomy and the present: materials of the IX All-Ukrainian scientific conference, April 13, 2020 / eds.: V.F. Zabolotny, O.V. Mozgovyi. - Vinnytsia: LTD "Tvory". - P.18-23. https://ui.adsabs.harvard.edu/abs/2020aspr.conf...18M/abstract

14. Steklov E.A., Steklov A.F., Vidmachenko A.P., Dashkiev G.N. Observations of Twilight Bolide with Using of "Churyumov Fireball Network" // 48th Lunar and Planetary Science Conference, held 20-24 March 2017, Woodlands, Texas. LPI Co. 1964, id.1327. https://ui.adsabs.harvard.edu/abs/2017LPI....48.1327S/abstract

15. Steklov A.F., Zhilyaev B.E., Vidmachenko A.P. Space invasion. As Is // 18-th Gamow Summer School "Astronomy and beyond: astrophysics, cosmology, cosmomicrophysics, astropartickle physics, radioastronomy and astrobiology". August 12-18, 2018, Odessa, Ukraine. - P.49. https://ui.adsabs.harvard.edu/abs/2018abac.conf...49S/abstract

16. Zhilyaev B.E., Steklov A.F., Vidmachenko A.P., et al. Rarefaction waves in meteor traces // 51st Lunar and Planetary Science Conference, held 16-20 March, 2020 at The Woodlands, Texas. LPI Contribution No. 2326, 2020, id.1098. https://ui.adsabs.harvard.edu/abs/2020LPI....51.1098Z/abstract 


\section{Фізичні характеристики космічного вторгнення}

Жиляєв Б.Ю., Відьмаченко А.П., Стєклов О.Ф.

Головна астрономічна обсерваторія НАН України, 03143, м. Київ, вул. Академіка Заболотного, 27

У цій роботі представлено приклад застосування теоретичних розробок з деяких питань фізики космічних вторгнень. Вплив коливань яскравості та “хитання" в метеорному сліді, який ми виявили, дозволяє отримати оцінки деяких характеристик метеора шляхом вимірювання частоти змін яскравості в сліді $\left(f_{c}\right)$ та метеороїдних коливань $\left(f_{m}\right)$, якщо його швидкість і висота відомі. На основі запропонованої «техніки налаштування» можна визначити характеристики метеора при односторонніх спостереженнях. Для цього ми встановили початкові параметри для моделі метеороїдної динаміки за збігом розрахункових та виміряних значень частот $f_{c}$ та $f_{m}$. Наше моделювання дозволяє нам знайти висоту, на якій співвідношення частот $f_{c} / f_{m}$ збігається зі значенням, виявленим при вибуху метеороїда. Використовуючи цю “техніку налаштування" та припускаючи мінеральний склад метеора, ми знайшли оцінки для початкової швидкості $21 \mathrm{~km} / \mathrm{c}$ та маси 850 кг метеороїда, який досяг критичного значення поверхневої швидкості на висоті близько 20,9 км приблизно за 7,9 с із залишковою масою близько 13,9 кг та залишковою швидкістю близько 10,9 км/с. В цей момент метеороїд вибухнув.

Ключові слова: космічні вторгнення, астрономічні спостереження, фотометрія, метеори.

\section{Физические характеристики космического вторжения}

Жиляев Б.Е., Видьмаченко А.П., Стеклов А.Ф

Главная астрономическая обсерватория НАН Украины, 03143, г. Киев, ул. Академика Заболотного, 27

В данной статье представлен пример применения теоретических разработок по некоторым вопросам физики космических вторжений. Обнаруженный нами эффект колебаний яркости и «качания» метеорного следа позволяет получить оценки некоторых характеристик метеора, измеряя частоту изменения яркости в следе $\left(f_{c}\right)$ и колебания метеороида $\left(f_{m}\right)$, если известны его скорость и высота. На основе предложенной «методики настройки» можно определять характеристики метеора при односторонних наблюдениях. Для этого зададим исходные параметры модели динамики метеороида по совпадению расчетных и измеренных значений частот $f_{c}$ и $f_{m}$. Наше моделирование позволяет нам найти высоту, на которой отношение частот $f_{c} / f_{m}$ совпадает со значением, найденным при взрыве метеороида. Используя эту «технику настройки» и предполагая минеральный состав метеора, мы получили оценки начальной скорости $21 \mathrm{~km} / \mathrm{c}$ и массы 850 кг метеороида, которые достигли критического значения поверхностной скорости на высоте около 20,9 км примерно за 7,9 с при остаточной массе около 13,9 кг и остаточной скорости около 10,9 км/с. В этот момент метеороид взорвался.

Ключевые слова: космические вторжения, астрономические наблюдения, фотометрия, метеоры.

Надійшла до редакції / Received

Виправлена авторами / Revised

Прийнята до друку / Accepted

28.12 .2020 